\title{
The Film Life of Pi as a Multimedia Tool in English Language Classrooms of Engineering Colleges in Gujarat- An ESP Approach
}

\author{
Barnali Chetia ${ }^{1}$ \& Dharna Bhatt ${ }^{2}$ \\ ${ }^{1}$ Assistant Professor, Indian Institute of Information Technology Vadodara. \\ ORCID: oooo-ooo3-3243-2361. Email: barnali@iiitvadodara.ac.in \\ ${ }^{2}$ Research Scholar, Indian Institute of Information Technology Vadodara. \\ ORCID: oooo-ooo1-9495-0346Email: dharnapandya@gmail.com
}

\begin{abstract}
ESP advocates the designing of special courses instead of one multi-purpose course, to suit the needs of different courses of students. The curriculum of English as a course in Engineering Institutes differs from other disciplines in Arts, Commerce and Science colleges. Use of films as a multimedia tool and as an ESP approach in English classrooms of Engineering Institutes has become inevitable. For many students, films are their initial contact with English-speaking culture and a fun way to relax and also learn at the same time. The present study tries to examine the use of films as a multimedia tool in the English language classrooms of Engineering Institutes of Gujarat. The film Life of Pi by Ang Lee is considered as a major instrument for the present study. The study was conducted on a sample of 315 students pursuing their B.Tech in different Government Engineering colleges of Gujarat, India. The study was accomplished by using the survey and observation method. The survey questionnaire was used as a major instrument for the data collection of the study. The results suggests that Films as a teaching tool motivates student to learn English in second language classrooms and also helps them to understand and enhance their second language skills.
\end{abstract}

Keywords: ESP, Second Language Acquisition, Multimedia, Life of Pi

\section{Introduction:}

Second language acquisition theory seeks to quantify how and by what processes individuals acquire a second language. Gregg (1999) claims that modern second language acquisition (SLA) research as a scientific discipline developed since world war second. It is observed that Second language teachers are aware of the fact that students bring into the classroom varied attitudes, experiences, strategies and beliefs. Studies have shown that some students believe that one cannot master a second language without studying its grammar or acquiring as large a vocabulary as possible. Some others believe that language learning simply means learning to translate from one's native language. Some even believe that one cannot comprehend written materials in English unless one reads every word slowly and carefully. These beliefs are part of second language learner's consciously or unconsciously acquired knowledge base in general and language learning in particular and these constitutes as one of the variables which significantly influence

(C) AesthetixMS 2020. This Open Access article is published under a Creative Commons Attribution Non-Commercial 4.0 International License (http://creativecommons.org/licenses/by-nc/4.0/), which permits non-commercial re-use, distribution, and reproduction in any medium, provided the original work is properly cited. For citation use the DOI. For commercial re-use, please contact editor@rupkatha.com. 
second language acquisition. According to the constitution of India, English is the second official language of India. And acquisition of English as a second language is of paramount importance in this country.

During the fifties, the three language formula was adopted. It gives due importance to the regional languages and attempts to promote national integration and national identity through a national link language that serves as a "Window of the World". In 1964 an Education Commission was set up to resolve the question of medium. The commission discussed this question and proposed that mother tongue should be used up to the highest level of instruction, but English should be taught both as a subject and as a library language at higher levels. As a result of the implementation of this proposal, mother tongue got precedence over English language. The trend during the past two decades has however been remarkably favouring English. The result can be seen in the forms of English medium schools which have cropped up like mushrooms in urban areas.

At present, English dominates functional domains in the widest possible register range. In India, English Language Teaching (ELT) has three fundamental approaches. Namely, English for Academic Purpose (EAP), English for Occupational Purpose (EOP) and English for Specific Purpose (ESP). ESP refers to the teaching of English language for specific need, where it advocates the designing of special courses instead of one multi-purpose course, to suit the needs of different courses of students. ESP is particularly used for teaching English to students of science and technology (EST). The curriculum of English as a course in Engineering Institutes differs from other disciplines in Arts, Commerce and Science colleges. It mainly differs in three aspects, such as, relevance, register and style. The aim of the courses is to enable the students of engineering to learn certain micro and macro skills in the English Language and use them effectively.

One of the problems that non-native English language learners face is the lack of interaction in the language at home, school, or neighbourhood; which is generally understood to boost language learning through providing the necessary language input for spoken language learning (Bahrani, Tam, \& Zuraidah, 2012). Teaching of English to Engineering students in India has always been a challenging task. This is because of lack of motivation. It is observed that as the learners join engineering colleges after crossing teenage, there is a lack of initiative and commitment towards acquiring the language skills at that stage. Proficiency in English is considered as one of the important employability skills. Only technical knowledge without soft skills shall not fetch students a good job or help them measure up in the workplace. In India, Multinational Corporations (MNCs) and Information Technology (IT) companies recruit engineering graduates who have good English communication skills. Thus students of engineering colleges are forced to upgrade their communication skills in English and other soft skills.

\section{Objectives:}

According to the constitution of India, English with the status of second official language, is used in all educational institutes, colleges, universities, and private and government offices as the medium of official communication. Even though it is an important language in every aspect of life, students are still not focusing in language learning. Therefore, the new era assigns new challenges and duties on the modern language teachers. They try to find ways and materials to teach language skills more effectively. They also try to make language classroom more interesting and productive. The tradition of English teaching has been drastically changed with the remarkable entry of technology. Multimedia provides myriad options as making teaching 
3 The Film Life of Pi as a Multimedia Tool in English Language Classrooms of Engineering Colleges in Gujarat- An ESP Approach

interesting and also making teaching more productive in terms of improvements. Use of films as multimedia tool provides exposure to the real language.

In rural India, it is observed that more often than not, the spoken English skills of teachers are also compromised. In some cases even English teachers as the available source of language input in formal classroom setting, lack the sufficient knowledge in second language (Curtis, 2003). Considering this issue, various audiovisual technologies could be employed in non-native ESL learning contexts that can provide opportunities for communicative English through different authentic materials, which may not have been initially produced or used for language learning purpose (Yuksel \& Tanriverdi, 2009).

Films are a shift from the conventional and offer students realistic learning environments (Sherman, 2003). By making use of films in the English classroom, students can enhance their vocabulary awareness and they can even make their pronunciation and intonation much better (Curtis, 2003). Therefore, the main purpose of the study is to understand, how tech-savvy students use films to enhance their English language skills inside and outside of the classroom. It is important to study on this topic because this study is going to help students as well as teachers to learn about the impact and usefulness of films as a multimedia tool and how this tool can be very useful to enhance English language skills. This study is based on the research questions as followed: (1) How ESP learners use films (Life of Pi for this study) to enhance their English language skills? (2) What is the impact of the film Life of Pi on enhancing English language skills?

\section{Method \& Procedure:}

Sample: Sampling technique has been used for this survey. The survey was carried out with a total sample of 315 students pursuing their B.Tech. at nine different government engineering colleges in Gujarat. The students who have participated in this study fall under the age group of $17-21$ years.

\begin{tabular}{|l|l|l|}
\hline Gender & Frequency & Percentage \\
\hline Male & 274 & 86.98 \\
\hline Female & 41 & 13.02 \\
\hline Total & 315 & 100 \\
\hline
\end{tabular}

Following is the list of selected Engineering colleges in Gujarat.

\begin{tabular}{|l|l|l|l|}
\hline $\begin{array}{l}\text { Sr. } \\
\text { No. }\end{array}$ & Engineering College Name & $\begin{array}{l}\text { Geographical } \\
\text { division of Gujarat }\end{array}$ & $\begin{array}{l}\text { Number of } \\
\text { Sample }\end{array}$ \\
\hline 1. & $\begin{array}{l}\text { Birla VishvakarmaMahavidyalaya Engineering } \\
\text { College (BVM) Vallabh Vidhyanagar }\end{array}$ & Central Gujarat & 35 \\
\cline { 1 - 2 } 2. & Vishwakarma Government Engineering College & & 35 \\
\cline { 1 - 2 } 3. & Government Engineering College Gandhinagar & North Gujarat & 35 \\
\hline 4. & Government Engineering College Patan & & 35 \\
\hline
\end{tabular}




\begin{tabular}{|l|l|l|l|}
\hline 5. & Government Engineering College Bharuch & \multirow{2}{*}{ South Gujarat } & 35 \\
\cline { 1 - 2 } 6. & Government Engineering College Valsad & & 35 \\
\hline 7. & Government Engineering College Bhavnagar & \multirow{2}{*}{ Saurashtra } & 35 \\
\cline { 1 - 2 } 8. & Government Engineering College Rajkot & & 35 \\
\cline { 1 - 1 } 9 & Shantilal Shah Engineering College & Total & 35 \\
\hline & & & 315 \\
\hline
\end{tabular}

\section{Instruments of Data Collection:}

The study was conducted by using the survey and observation method. The questionnaire was used as a major instrument for the data collection of the study. The sample film "Life of Pi" was used for the assessment of the parameters.

Ang Lee's film "Life of Pi" is based on Yann Martel's novel of the same name. It is a story of a young castaway who faces immeasurable hardships on the high seas. Survival, faith and miracles in order to present a formula for harmony of life are the different themes of the movie. This movie is considered to be useful to enhance English language skills because of the following reasons:

Simple English

Captivating story with many dimensions

Visually stunning

One speaker

Use of figurative language and soliloquies.

\section{Data Analysis:}

The data obtained from the questionnaire is analyzed quantitatively using frequencies and percentages in the following section. Each research question has been analyzed and discussed.

\section{Analysis and interpretation of the data:}

Table 4.1: Did you enjoy the movie "Life of Pi"?

\begin{tabular}{|l|l|l|l|}
\hline $\begin{array}{l}\text { Sr. } \\
\text { No. }\end{array}$ & $\begin{array}{l}\text { Agreement } \\
\text { (Statement) }\end{array}$ & Frequency & Percentage \\
\hline 1. & Yes & 300 & 95.24 \\
\hline 2. & No & 15 & 4.76 \\
\hline & Total & 315 & 100.00 \\
\hline
\end{tabular}

4.1: Frequency Distribution (Did you enjoy the movie "Life of Pi”?) 
5 The Film Life of Pi as a Multimedia Tool in English Language Classrooms of Engineering Colleges in Gujarat- An ESP Approach

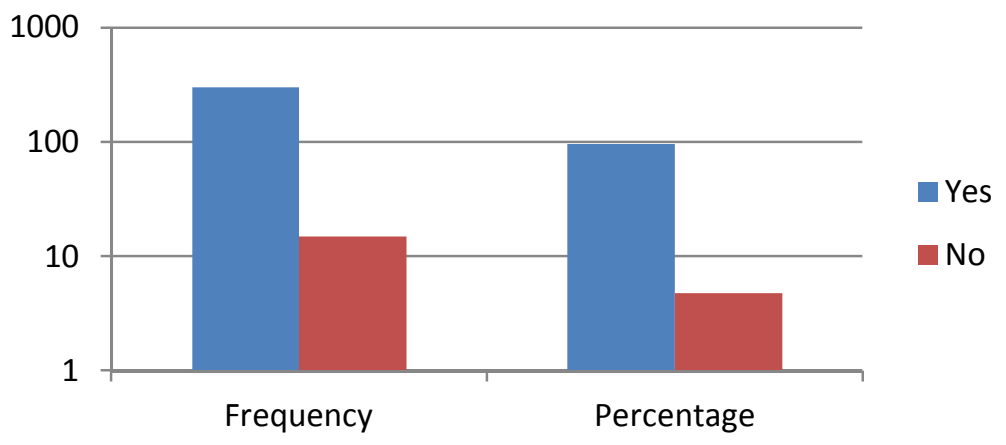

Figure 4.1: Graphical Distribution (Did you enjoy the movie "Life of Pi”?)

Based on the findings, it can be said that respondents had a positive attitude towards the film "Life of Pi" and majority of the students enjoyed the movie.

Table 4.2: Test Questions Based on the film "Life of Pi".

\begin{tabular}{|c|c|c|c|c|c|}
\hline $\begin{array}{l}\text { Sr. } \\
\text { No. }\end{array}$ & Questions & $\begin{array}{l}\text { Right } \\
\text { Answer } \\
\text { Frequency }\end{array}$ & $\begin{array}{l}\text { Right } \\
\text { Answer } \\
\text { Percentage }\end{array}$ & $\begin{array}{l}\text { Wrong } \\
\text { Answer } \\
\text { Frequency }\end{array}$ & $\begin{array}{l}\text { Wrong Answer } \\
\text { Percentage }\end{array}$ \\
\hline 1 & $\begin{array}{l}\text { Who is the author of novel Life } \\
\text { of Pi? }\end{array}$ & 209 & 66.35 & 106 & 6.56 \\
\hline 2 & $\begin{array}{l}\text { Who directed the film Life of } \\
\text { Pi? }\end{array}$ & 193 & 61.27 & 122 & $7 \cdot 55$ \\
\hline 3 & What is Life of Pi about? & 277 & 87.94 & 38 & 2.35 \\
\hline 4 & $\begin{array}{l}\text { Piscine Molitor Patel is named } \\
\text { after? }\end{array}$ & 228 & 72.38 & 87 & $5 \cdot 38$ \\
\hline 5 & $\begin{array}{l}\text { Why does Pi's family have to } \\
\text { move country? }\end{array}$ & 259 & 82.22 & 56 & 3.47 \\
\hline 6 & $\begin{array}{l}\text { What is Pi's companion's } \\
\text { name? }\end{array}$ & 292 & 92.70 & 23 & 1.42 \\
\hline 7 & $\begin{array}{l}\text { How many days does Pi survive } \\
\text { on the raft? }\end{array}$ & 255 & 80.95 & 60 & 3.71 \\
\hline 8 & $\begin{array}{l}\text { What was the name of the ship } \\
\text { that sank? }\end{array}$ & 222 & 70.48 & 93 & 5.75 \\
\hline 9 & $\begin{array}{l}\text { Where did Pi's lifeboat come } \\
\text { ashore? }\end{array}$ & 199 & 63.17 & 116 & 7.18 \\
\hline
\end{tabular}




\begin{tabular}{|c|c|c|c|c|c|}
\hline 10 & $\begin{array}{l}\text { Who has the worst sea } \\
\text { sickness? }\end{array}$ & 119 & $37 \cdot 78$ & 196 & 12.13 \\
\hline 11 & Where does Pi grow up? & 253 & 80.32 & 62 & 3.84 \\
\hline 12 & $\begin{array}{l}\text { How does Richard Parker get } \\
\text { his name? }\end{array}$ & 104 & 33.02 & 211 & 13.06 \\
\hline 13 & $\begin{array}{l}\text { What was Pi grateful to Richard } \\
\text { Parker for? }\end{array}$ & 207 & $65 \cdot 71$ & 108 & 6.68 \\
\hline 14 & $\begin{array}{l}\text { What according to } \mathrm{Pi} \text { is life's } \\
\text { only true opponent? }\end{array}$ & 129 & 40.95 & 186 & 11.51 \\
\hline 15 & $\begin{array}{l}\text { What aspect of Pi's personality } \\
\text { makes his survival struggle } \\
\text { even harder? }\end{array}$ & 202 & 64.13 & 113 & 6.99 \\
\hline 16 & $\begin{array}{l}\text { In Pi's second story, the cook is } \\
\text { paralleled to whom? }\end{array}$ & 175 & $55 \cdot 56$ & 140 & 8.66 \\
\hline 17 & $\begin{array}{l}\text { Pi's father teaches him and his } \\
\text { brother, Ravi, a lesson about } \\
\text { wild animals by...? }\end{array}$ & 221 & 70.16 & 94 & 5.82 \\
\hline 18 & $\begin{array}{l}\text { Pi sees an orangutan named } \\
\text { Orange Juice floating on a raft } \\
\text { made of...? }\end{array}$ & 198 & 62.86 & 117 & 7.24 \\
\hline 19 & $\begin{array}{l}\text { What becomes Pi's most } \\
\text { valuable tool in training } \\
\text { Richard Parker? }\end{array}$ & 245 & $77 \cdot 78$ & 70 & $4 \cdot 33$ \\
\hline 20 & $\begin{array}{l}\text { After his rescue, } \mathrm{Pi} \text { is } \\
\text { interviewed by two officials } \\
\text { from the...? }\end{array}$ & 132 & 41.90 & 183 & 11.32 \\
\hline & Mean & $205 \cdot 95$ & 65.38 & 109.05 & 34.62 \\
\hline
\end{tabular}

4.2: Frequency Distribution (Question Based on the movie "Life of Pi”) 
7 The Film Life of Pi as a Multimedia Tool in English Language Classrooms of Engineering Colleges in Gujarat- An ESP Approach

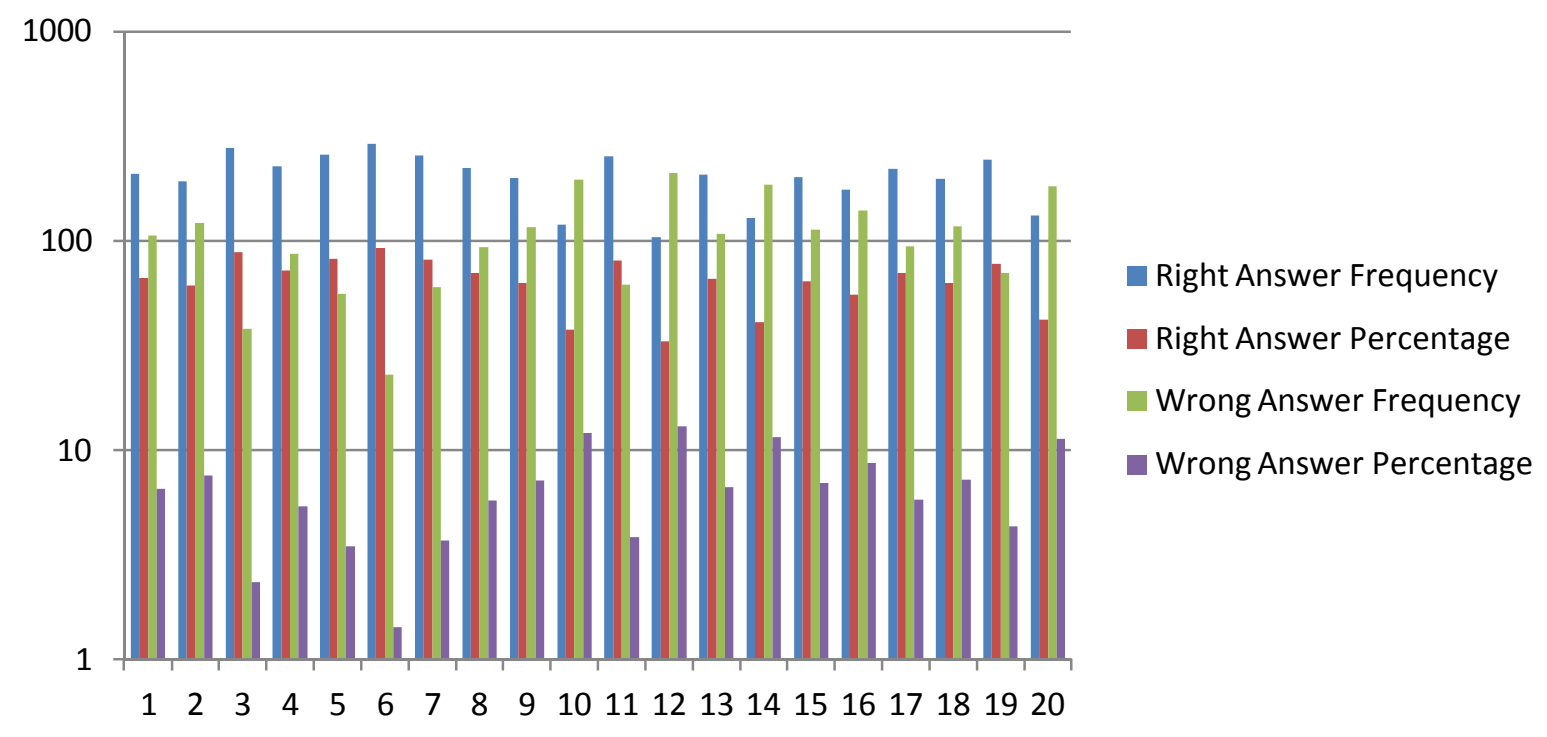

Figure 4.2: Graphical Distribution (Questions Based on the Movie "Life of Pi”)

Based on the findings, the mean of the frequency of the right answers is $205.95(65.38 \%)$ and the mean of the frequency of the wrong answer is 109.05 (34.62\%) The result suggests that the memorability component is more with the usage of visual media.

Table 4.3: Should movies be integrated in syllabus design for teaching learning Process?

\begin{tabular}{|l|l|l|l|}
\hline $\begin{array}{l}\text { Sr. } \\
\text { No. }\end{array}$ & $\begin{array}{l}\text { Agreement } \\
\text { (Statement) }\end{array}$ & Frequency & Percentage \\
\hline 1 & Strongly agree & 66 & 20.95 \\
\hline 2 & Agree & 144 & 45.71 \\
\hline 3 & $\begin{array}{l}\text { Strongly } \\
\text { disagree }\end{array}$ & 26 & 8.25 \\
\hline 4 & Disagree & 10 & 3.17 \\
\hline 5 & Neutral & 69 & 21.90 \\
\hline
\end{tabular}

4.3: Frequency Distribution (Should movies be integrated in syllabus design for teaching learning Process?) 


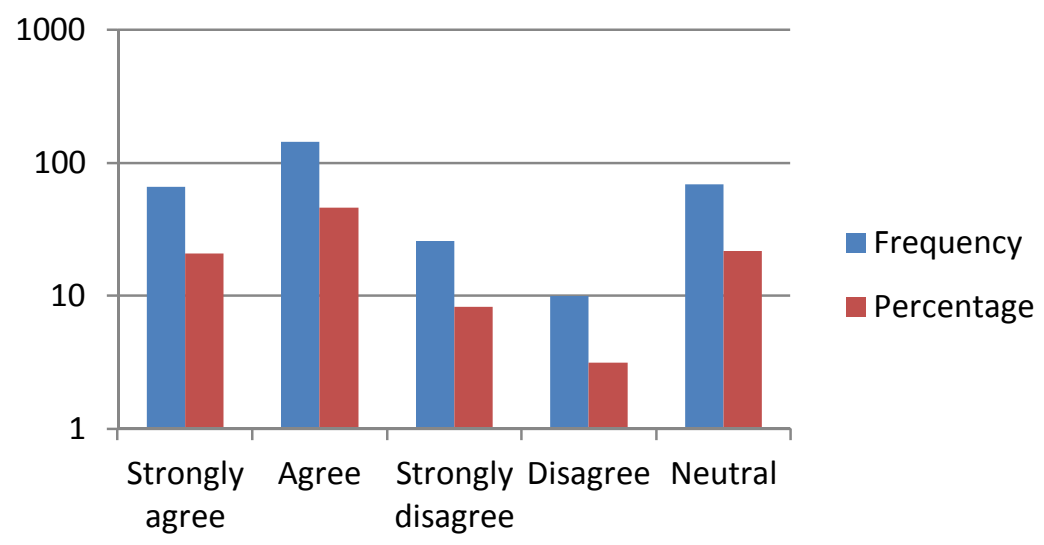

Figure 4.3: Graphical Distribution (Should movies be integrated in syllabus design for teaching learning Process?)

With the development in the field of education, technology based teaching method has taken the place of the traditional chalk-talk method. Moreover, based on the technology savvy students (the subjects are from engineering background) views, films should be integrated in syllabus. In addition, majority of the students are in favour of multimedia in the form of films becoming a part of their syllabus.

Table 4.4: Do you think that your movie preference will affect your learning?

\begin{tabular}{|l|l|l|l|}
\hline $\begin{array}{l}\text { Sr. } \\
\text { No. }\end{array}$ & $\begin{array}{l}\text { Agreement } \\
\text { (Statement) }\end{array}$ & Frequency & Percentage \\
\hline 1 & Strongly agree & 44 & 13.97 \\
\hline 2 & Agree & 151 & 47.94 \\
\hline 3 & Strongly disagree & 23 & 7.30 \\
\hline 4 & Disagree & 15 & 4.76 \\
\hline 5 & Neutral & 82 & 26.03 \\
\hline
\end{tabular}

4.4: Frequency Distribution (Do you think that your movie preference will affect your learning?) 
9 The Film Life of Pi as a Multimedia Tool in English Language Classrooms of Engineering Colleges in Gujarat- An ESP Approach

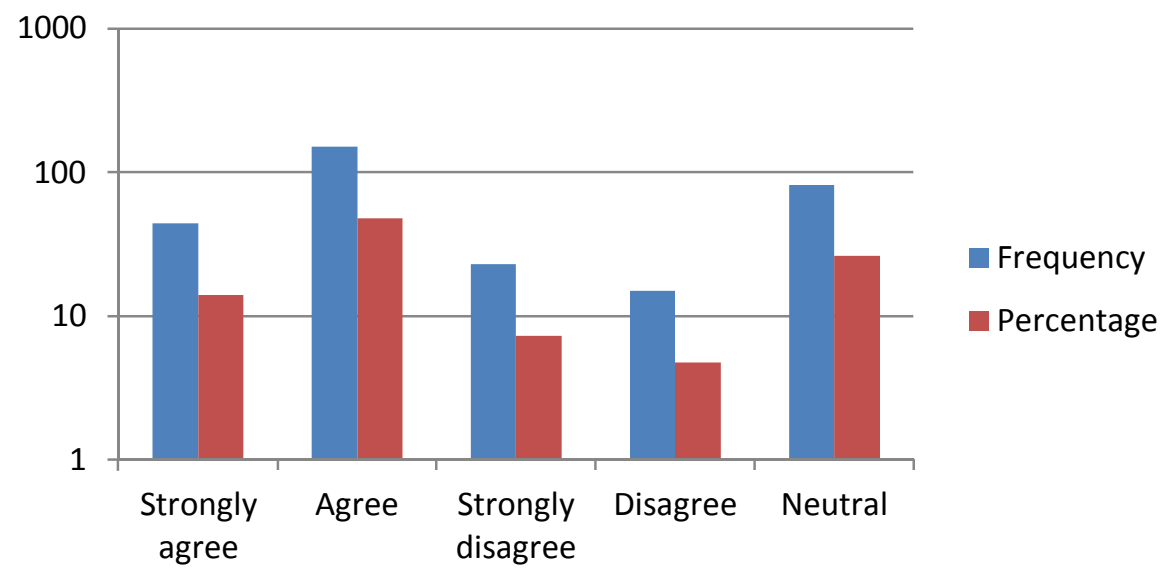

Figure 4.4: Graphical Distribution (Do you think that your movie preference will affect your learning?)

Based on the findings many of the students felt that their movie preference affect their language learning.

Table 4.5: Do you think that "Life of Pi" is useful to enhance English Language Skills?

\begin{tabular}{|l|l|l|l|}
\hline $\begin{array}{l}\text { Sr. } \\
\text { No. }\end{array}$ & $\begin{array}{l}\text { Agreement } \\
\text { (Statement) }\end{array}$ & Frequency & Percentage \\
\hline 1 & Strongly agree & 46 & 14.60 \\
\hline 2 & Agree & 181 & 57.46 \\
\hline 3 & Strongly disagree & 13 & 4.13 \\
\hline 4 & Disagree & 13 & 4.13 \\
\hline 5 & Neutral & 62 & 19.68 \\
\hline
\end{tabular}

4.5: Frequency Distribution (Do you think that "Life of Pi" is useful to enhance English Language Skills?) 


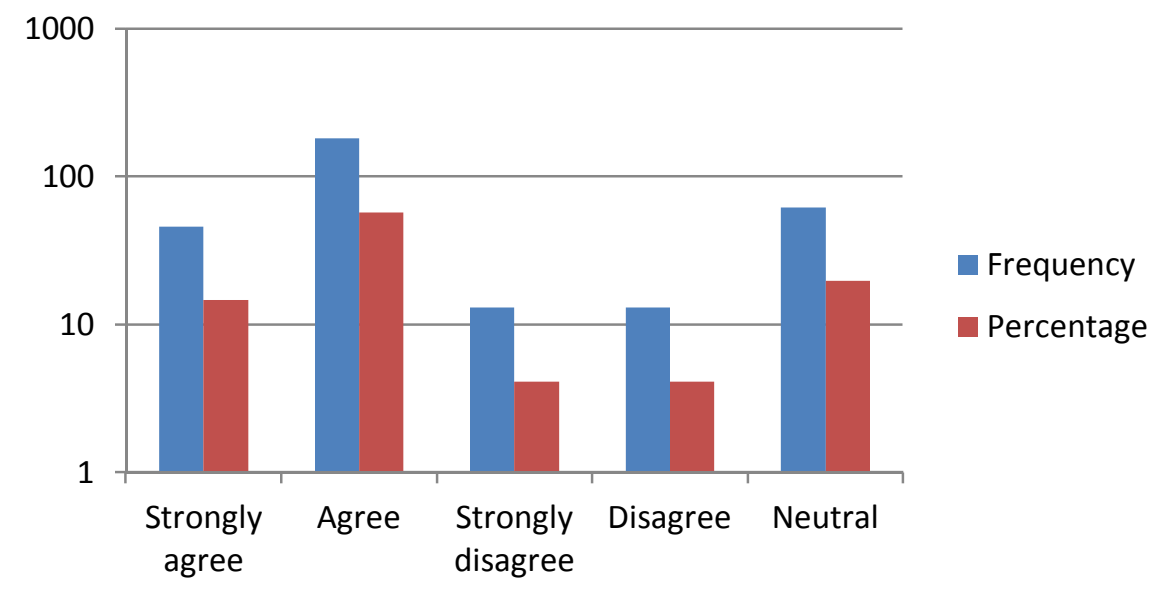

Figure 4.5: Graphical Distribution (Do you think that "Life of Pi" is useful to enhance English Language Skills?)

"Life of Pi" is an interesting film which is based on Yann Martel "s book adaptation. Majority of the students enjoyed the film "Life of Pi". They found it useful to enhance their English language skills in the form of metaphors, similes, puns and various other figures of speech.

Table 4.6: Which language function(s) have you acquired from the movie "Life of Pi"?

\begin{tabular}{|l|l|l|l|}
\hline $\begin{array}{l}\text { Sr. } \\
\text { No. }\end{array}$ & Agreement (Statement) & Frequency & Percentage \\
\hline 1 & Grammar & 46 & 14.60 \\
\hline 2 & Communication Skills & 108 & 34.29 \\
\hline 3 & Vocabulary & 69 & 21.90 \\
\hline 4 & LSRW & 85 & 26.98 \\
\hline 5 & All the Above & 153 & 48.57 \\
\hline
\end{tabular}

4.6: Frequency Distribution (Which language function(s) have you acquired from the movie "Life of Pi”?) 
1 The Film Life of Pi as a Multimedia Tool in English Language Classrooms of Engineering Colleges in Gujarat- An ESP 1 Approach

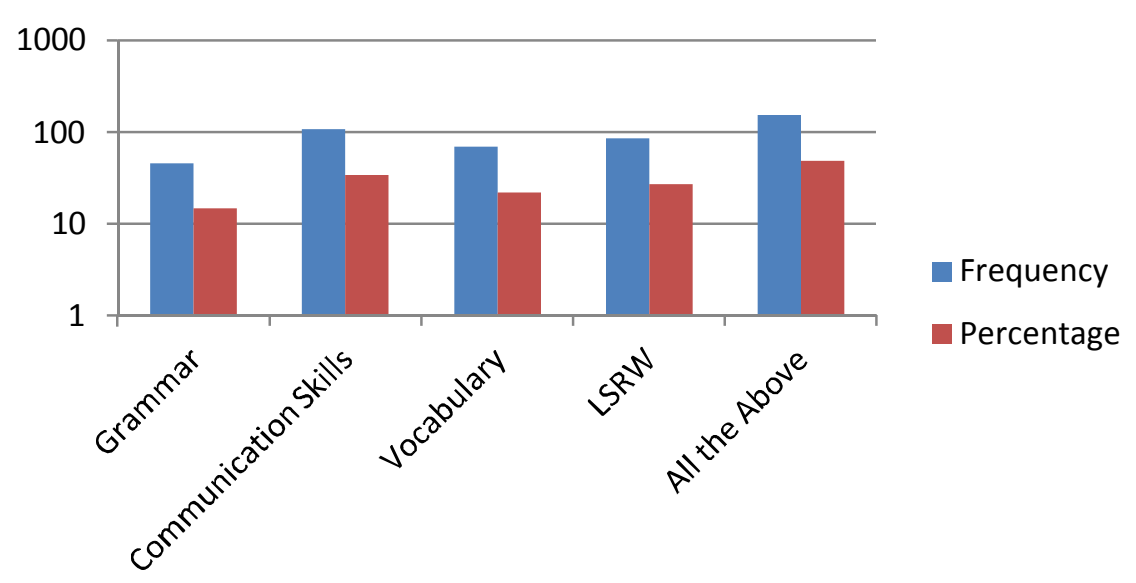

Figure 4.6: Graphical Distribution (Which language function(s) have you acquired from the movie "Life of Pi"?)

Based on the responses, it is observed that respondents had major improvement in LSRW. So, it has been proved that majority of the students improved their language skills. Thus, this method can be applied in teaching and learning English language skills making the process of teaching and learning interesting and enjoyable.

Table 4.7: Which skills have you developed through the movie "Life of Pi"?

\begin{tabular}{|l|l|l|l|}
\hline $\begin{array}{l}\text { Sr. } \\
\text { No. }\end{array}$ & $\begin{array}{l}\text { Agreement } \\
\text { (Statement) }\end{array}$ & Frequency & Percentage \\
\hline 1 & Listening & 236 & 74.92 \\
\hline 2 & Speaking & 153 & 48.57 \\
\hline 3 & Reading & 91 & 28.89 \\
\hline 4 & Writing & 54 & 17.14 \\
\hline
\end{tabular}

4.7: Frequency Distribution (Which skills have you developed through the movie "Life of Pi"?) 


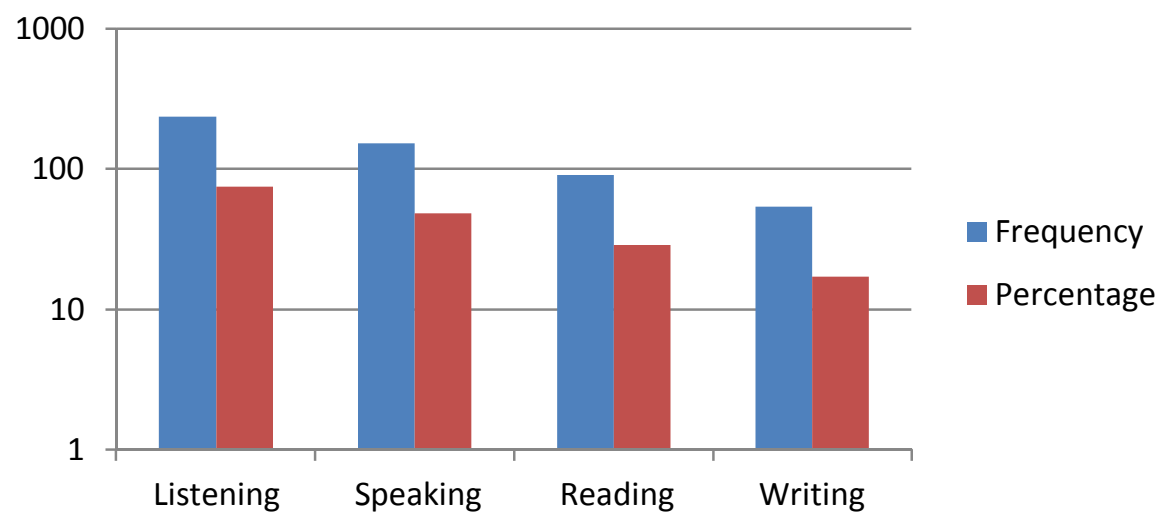

Figure 4.7: Graphical Distribution (Which skills have you developed through the movie "Life of Pi”?)

Based on the findings, majority of the subjects replied positively about the development of English language skills through the film "Life of Pi". Along with LSRW, the subjects learned ornamentation of spoken and written texts with the help of figures of speech, descriptive grammar and other linguistic parameters.

\section{Conclusion:}

The traditional chalk and talk method has gradually been replaced by the more modern and effective methods of language teaching. Films can be claimed as an effective teaching method which provides students a conducive environment to enhance their vocabulary skills and to learn English language. Easy accessibility and inexpensive usability of films can provide natural language learning environments for ESL learners.

It is observed that in ESL classrooms use of films for pedagogy has great potential. It is very important how a film is incorporated in the syllabus of an ESL classroom. Moreover, if teachers use this method in the classroom then student's motivation can be induced and flexibility in real occasions can be cultivated. Hence, enhancing the ability of learning English language skills can be easy and enjoyable. Films offer an innovative opportunity to help English teachers in an ESL classroom in teaching more effectively. It is believed that if this technology is adopted as a part of our teaching process, it would surely fill the gap between teachers and students. Thus, Films as a multimedia tool can be an important and effective ESP approach to teach English language skills in an ESL classroom.

\section{References}

Arora, Navita. (2012). English Language Teaching Approaches and Methodologies. Tata McGraw Hill Education Private Limited. New Delhi.

Brinton, D.M. (2001). The use of Media in Language Teachingec, in Celce-Murcia, M. (ed.) Teaching English as a second or foreign language (3rd ed., pp.459-475). Boston: Heinle and Heinle.

Bahrani, T., \& Tam, S. S. (2011). Technology and language learning: Exposure to TV and radio news and speaking proficiency. Kritika Kultura, 17, 144-160. 
Bahrani, T., \& Tam, S. S. (2012). Audiovisual news, cartoons, and films as authentic language input and language proficiency development. The Turkish Online Journal of Educational Technology, 11(4), 56-64.

Chun, Dorothy M. (2016). The Role of Technology in SLA Research Language Learning \& Technology. 20(2), 98-115.

Curtis, A. (2003). Making the most of movies in Canadian ESL classrooms. TESOL Ontario Conference Proceedings, 29(3), 29-32.

Curtis, A. (2007). Film in the ESL classroom: hearing the students" voice. In H. McGarrell (Ed.), Language Teacher Research in the Americas (pp. 41-53). Alexandria, VA: TESOL Association.

Damronglaohapan, S., \& Stevenson, E. Enhancing Listening Skills through Movie Clips on YouTube.

Ismaili, M. (2013). The effectivenessof using movies in the EFL classroom-a study conducted at South East European University. Academic Journal of Interdisciplinary Studies, 2(4), 121.

Kasapoğlu-Akyol, P. (2010). Using educational technology tools to improve language and communication skills of ESL students. Novitas-ROYAL (Research on Youth and Language), 4(2), 225-241.

Khan, A. (2015). Using films in the ESL classroom to improve communication skills of non-native learners. ELT Voices, 5(4), 46-52.

Li, X., \& Wang, P. (2015). A research on using English movies to improve Chinese college students' oral English. Theory and Practice in Language Studies, 5(5), 1096.

Patel, Chirag. (2013). Use of Multimedia Technology in Teaching and Learning communication skill: An Analysis. International Journal of Advancements in Research \& Technology. 2(7).

Sherman, J. (2003). Using authentic video in the language classroom. Cambridge: Cambridge University Press.

Yuksel, D. (2009). Effects of watching captioned movie clip on vocabulary development of EFL learners. The Turkish Online Journal of Educational Technology, 8(2), 48-54.

Appendices: Google questionnaire

\section{Life of Pi}

* Required

A. Name *

B. Gender *

Mark only one oval.

Male

Female

C. Semester *

Mark only one oval.

1st

2nd 
3rd

$4^{\text {th }}$

$5^{\text {th }}$

6th

7th

8th

Other:

D. Institute Name *

1. Did you enjoy the movie "Life of Pi"? *

Mark only one oval.

Yes

No

2. Who is the author of novel Life of Pi? *

Mark only one oval.

John Fisher

Yann Martel

Grace Leni

Martin Larkist

3. Who directed the film Life of Pi? *

Mark only one oval.

David Magee

Suraj Sharma

Yann Martel

Ang Lee

4. What is Life of Pi about? *

Mark only one oval.

A girl named Pi who grows up on a deserted island.

A stranded whizz kid who refers to himself as Pi

A boy named piscine who is trapped on a raft with a Bengal tiger whom he befriends

A man who has to survive solely on Ireland.

5. Piscine Molitor Patel is named after *

Mark only one oval.

A famous Indian government official

A famous landmark

A swimming pool 
1 The Film Life of Pi as a Multimedia Tool in English Language Classrooms of Engineering Colleges in Gujarat- An ESP

5 Approach

A close family relative.

6. Why does Pi's family have to move country? *

Check all that apply.

They want to move nearer their family.

His father intends to settle and sell the zoo animal in Canada.

They want to move to a different climate.

Pi's father decides that the political actions being taken are not to his liking.

7. What is Pi's companion's name? *

Mark only one oval.

Richard Parker

Peter Parker

Chai

Indigo Pearl

8. How many days does Pi survive on the raft? *

Mark only one oval.

139

227

294

114

9. What was the name of the ship that sank? *

Mark only one oval.

Titanic II

Tsimtsum

Panama Lady

10. Where did Pi's lifeboat come ashore? *

Mark only one oval.

Mexico

India

Bahamas

11. Who has the worst sea sickness? *

Mark only one oval.

Pi

Ravi

Richard Parker 
Orange Juice

12. Where does Pi grow up? *

Mark only one oval.

Munnar

Toronto

Zurich

Pondicherry

13. How does Richard Parker get his name? *

Mark only one oval.

Pi names him after favorite teacher.

His zookeeper names him after himself.

He resembles a famous actor named Richard Parker.

A clerical error

14. What was Pi grateful to Richard Parker for? *

Mark only one oval.

His weight kept the boat steadier.

He killed the dangerous hyena.

He distracted him from the despair of being utterly alone and having lost his family.

He provided warmth.

15. What does Pi say is life's only true opponent? *

Mark only one oval.

Death

Lack of faith in God

Despair

Fear

16. What aspect of Pi's personality makes his survival struggle even harder? *

Mark only one oval.

His allergy to cats

His sensitivity to sunlight

His vegetarianism

His fear of the ocean

17. In Pi's second story, the cook is paralleled to whom? *

Mark only one oval.

The zebra

The hyena 
1 The Film Life of Pi as a Multimedia Tool in English Language Classrooms of Engineering Colleges in Gujarat- An ESP

7 Approach

Richard Parker

Pi's survival instinct

18. Pi's father teaches him and his brother, Ravi, a lesson about wild animals by *

Mark only one oval.

feeding a wild goat to a tiger

playing a video tape of a lion circus stunt gone wrong

throwing fish into a shark tank

showing them a scar he received from a hyena

19. Pi sees an orangutan named Orange Juice floating on a raft made of *

Mark only one oval.

oars

wood planks

bananas

oranges

2o. What becomes Pi's most valuable tool in training Richard Parker? *

Mark only one oval.

A whip

A whistle

An oar

A megaphone

21. After his rescue, $P i$ is interviewed by two officials from the *

Mark only one oval.

Japanese Ministry of Transport

Japanese Department of Police

Japanese Shipping Association

Japanese Zoological Society

22. Which language function(s) have you acquired from the movie Life of Pi?(You may tick more than one) *

Check all that apply.

Grammar

Communication Skills

Vocabulary

Listening, Speaking, Reading, Writing,

All the Above 
23. Should movies be integrated in syllabus design for teaching learning Process? *

Mark only one oval.

Strongly disagree

Disagree

Neutral

Agree

Strongly agree

24. Do you think that your movie preference will affect your learning? *

Mark only one oval.

Strongly disagree

Disagree

Neutral

Agree

Strongly agree

25. Do you think that "Life of Pi" is useful to enhance English Language Skills? *

Mark only one oval.

Strongly disagree

Disagree

Neutral

Agree

Strongly agree

26. Which skill have you developed through the movie "Life of Pi " ?(You may tick more than one) * Check all that apply.

Listening

Speaking

Reading

Writing

Author's bio-note:

1. Dr. Barnali Chetia is an Assistant Professor (Linguistics) with IIIT Vadodara. She has completed her PhD in Linguistics from JNU, New Delhi. She has research interests in Applied Linguistics, Sociolinguistics, Second Language Acquisition, ELT, Gender Studies and Science Fiction. She is the editor of the book "Cradle Song-A Compendium of Indian Science Fiction Stories". She has further authored the book "The Language of English Advertisement Texts-Selected Essays". She is also associated with various organisations 
1 The Film Life of Pi as a Multimedia Tool in English Language Classrooms of Engineering Colleges in Gujarat- An ESP

9 Approach

like IRD (India), IJMRD (International), RAIS (U.S), ReiLA Journal, ELT Vibes as reviewer, editor and advisory board member.

2. Ms. Dharna Bhatt has obtained her B.A. and M.A. in English Literature from Mohan Lal Sukhadia University, Rajasthan and M.Phil in Indian Literature from Vardhman University, Rajasthan. She is pursuing her Ph.D. in English language teaching at Indian Institute of Information Technology Vadodara. Her current research is on multimedia and its effectiveness on second language learning. Other research interests include Applied Linguistics, ELT, Gender Studies and Indian literature. She has five years of teaching experience in different engineering colleges in Gujarat. She has attended as well as presented papers in various national and international conferences. 